\title{
O RAPTO DO RISO EM O ROMANCE DO PAVÃO MISTERIOSO
}

\author{
THE CAPTURE OF LAUGHTER IN O ROMANCE DO PAVÃO \\ MISTERIOSO
}

\author{
João Paulo FERNANDES*
}

\begin{abstract}
Resumo: O século XXI evidencia um percurso literário que se construiu ao longo de uma tradição literária que se mescla pela contemporaneidade, de modo que novos olhares menos contundentes apontam vieses que verticalizam os gêneros literários, permitindo em sua adjetivação a hibridez, seja pela sua linguagem comum, ou no que se assemelha a outras linguagens de sua composição figurativa. Dessa forma, o objetivo principal deste artigo é analisar o riso, que se metamorfoseia ao longo do poema O romance do pavão misterioso, de José Camelo de Melo Rezende, multifacetando-se pelo tom trágico legado pela épica grega, compreendido na obra pelo aspecto geográfico e interditos que contradizem o risível como característica primeira do cômico. A articulação teórico-crítica permitiu realizar a leitura da obra em interface à (de)formação do humor, pelas dualidades e/ou antagônicas proposições ora representadas por alguns elementos do insólito. Nessa perspectiva, o reforço teórico é oriundo das premissas iniciais de Tzvetan Todorov (2017) à Literatura Fantástica, Vladímir Propp (2002) até as considerações recentes de David Roas (2014) e Remo Ceserani (2006). Ainda nesse contexto, vale ressaltar o estudo proposto por George Desmeules (1997), que destaca a ambivalência da categoria a ser analisada. Em linhas conclusivas, pretende-se aproximar o humor e o fantástico que se mostram pelos reversos e deslocamentos, nos quais se alteram os sentidos do riso.
\end{abstract}

Palavras-chave: Literatura fantástica. Literatura popular. Poesia. Pavão misterioso. Metamorfose do riso.

\begin{abstract}
The $21^{\text {st }}$ century has revealed a literary trajectory that was constructed upon a literary tradition that is mixed to contemporaneity in a way that new less overwhelming views point bias that verticalize literary genres and allows for adjectivation such as hybrid, be it for its common language or for the similarity to other languages in its figurative composition. The main objective of this paper is to analyze the metamorphosization of laughter in the poem $O$ romance do pavão misterioso, by José Camelo de Melo Rezende, multifaceted in the tragic tune of the Greek epic, which is seen in the poem through geographic aspects and interdicts that disregard the risible as the first comic characteristic. The theoreticcritical articulation allowed for a reading, as an interface with the (de)formation of humor, through dualities and/or antagonistic propositions represented by uncommon elements. The theoretic sources come from the initial premises of Tzvetan Todorov (2017) on Fantastic Literature, Vladímir Propp (2002) and recent considerations by David Roas (2014) and Remo Ceserani (2006). It is, also, important to point out the studies proposed by George Desmeules (1997), that approaches the ambivalence of the category to be analyzed. In other words, the paper intends to approximate the humor and the fantastic that emerge through reverses and displacements in which risible senses are altered.
\end{abstract}

Keywords: Fantastic literature. Popular literature. Poetry. Pavão misterioso. Metamorphosis of the risible.

\footnotetext{
* Doutor em Letras pela Universidade Federal da Paraíba. Professor no Curso de Letras - Língua Portuguesa, no Instituto Federal da Paraíba. E-mail: proesia@yahoo.com. ORCID https://orcid.org/0000-0001-5679-0599
} 


\section{"Eu vou contar uma história..."}

José Camelo de Melo Rezende (1885-1964) é oriundo de Pilõezinhos, no Estado da Paraíba, hoje cidade, à época distrito pertencente a Guarabira - PB. Ambas cidades paraibanas, localizadas na delimitação geográfica do Piemonte da Borborema - comercialmente, a última é reconhecida como Rainha do Brejo. A Academia Brasileira de Literatura de Cordel o reconhece como patrono da cadeira ${ }^{\circ}$ 5, ocupada pelo paraibano José João dos Santos (Mestre Azulão), legando lugar de imortalidade por produzir um notável lirismo em obras como $O$ romance do pavão misterioso, Aprígio Coutinho e Neusa, A verdadeira história de Joãozinho e Mariquinha, Coco-verde e Melancia, entre outros.

Sua principal obra é o já citado poema $O$ romance do pavão misterioso, antes de ser "raptado" por João Melchíades e se tornar um dos maiores romances da Literatura de Cordel já publicados em folheto. Composição, inicialmente guardada na memória, era declamada de cor a cada apresentação do autor, aspecto que facilitou a posse por Melchíades, também cordelista, contemporâneo de Rezende.

A poesia, aqui, não será adjetivada, evitando sua redução quanto à forma de cordel, à linguagem matuta ou ao suporte. Interessa saber o alcance de seu efeito estético, que perpassa todos esses aspectos e estabelece diálogo entre o clássico e o contemporâneo pela linguagem poética, de modo que uma leitura crítica acentue outras ambivalências como o fantástico e o humor. Olha-se para além da beleza feminina que faz lembrar Helena de Troia, outras nuances serão contempladas no que tange ao riso e ao não riso.

O romance do pavão misterioso é narrado em 141 estrofes de seis versos, metricamente, cada verso com sete sílabas, compondo rimas do tipo "XAXAXA". Após anos de batalha entre o dito e o escrito, acrescentou-se em edições recentes uma estrofe final, em acróstico, na qual credita-se JOSECAMELO como o verdadeiro autor. Vale ressaltar que o uso do acróstico nos folhetos, usado como marca de autoria, data de bem antes, uma vez que editores costumavam assinar como autores.

Dois territórios, duas famílias fazem parte do enredo, antecipando uma interseção direta com a épica grega, evidenciada pelas jovens mulheres gregas, Helena e Creuza, ambas raptadas de seus castelos, sendo a última ancorada no imaginário do conto de fadas. Dessa forma, o pathos se assemelha no clássico e se distancia pelo fantástico presente em $O$ romance do pavão misterioso. Sendo assim, o argumento da análise se mostra desde o título "O rapto do riso", cujo mérito é mostrar as possíveis metamorfoses do humor, as quais tangenciam o risível e se aproximam do aparente paradoxo. 


\section{As cores do pavão e o rapto do riso}

Multiplicam-se os textos que primam pela terminologia, que nomeiam a literatura ao longo dos séculos, realizando um mapeamento datado acerca das obras e dos seus autores. Tais práticas podem estabelecer olhares anacrônicos e/ou estáticos no que diz respeito à linguagem literária, que transcende os limites do tempo e do espaço, por mais didáticos que sejam esses registros. Por outro lado, recorre-se ao diálogo estabelecido, diacronicamente, no qual é passível observar convergências entre as narrativas ou personagens, por mais opostos que se pareçam.

Nesse plano, qual seria a classificação da obra $O$ romance do pavão misterioso de acordo com a teoria literária? Como explicar os elementos que transcendem o gênero literário categorizado? Pode o cordel romper com a tradição literária, revelando novas cores da tragédia, do fantástico e do humor? Se sim, como explicar suas novas características?

A princípio, o cordel, que é considerado como "sinônimo de poesia popular em verso", como destacam Ana Marinho e Hélder Pinheiro (2012), amplia-se ao território da literatura de cordel quando seu repertório de versos perpassa outros tipos de textos e narra "histórias de batalhas, amores, sofrimentos, crimes, fatos políticos e sociais do país e do mundo, as famosas disputas entre cantadores" (p. 17). Nota-se, deste então, a interseção de aspectos formais e temáticos que materializam vozes de poetas populares.

\footnotetext{
A expressão "literatura de cordel" foi inicialmente empregada pelos estudiosos da nossa cultura para designar os folhetos vendidos nas feiras, sobretudo em pequenas cidades do interior do Nordeste, em uma aproximação como o que acontecia em terras portuguesas. (MARINHO; PINHEIRO, 2012, p. 18).
}

Situado o folheto de cordel, busca-se pelos distanciamentos e pelas aproximações das composições poéticas, a exemplo do que se encontra nos romances, escritos em sextilhas, com rimas em $\mathrm{ABCBDB}$ ou XAXAXA, esse último tipifica as rimas no aqui mencionado $O$ romance do pavão misterioso, de José Camelo de Melo Rezende. Sendo este o romance de aventura e amor um dos mais representativos aos poetas populares,

[...] conta a história de um rapaz apaixonado que viaja em um pássaro gigante até o quarto da sua amada. Depois de muitas aventuras, consegue livrar a donzela da tirania do pai, casam-se e vivem juntos para sempre. Misturam-se temas do passado com proezas e façanhas tornadas possíveis com o uso da tecnologia, o romance encanta aos leitores de qualquer época. (MARINHO; PINHEIRO, 2012, p. 36-37).

Para além da aventura e do amor, temas comuns a outras narrativas literárias, especialmente clássicas, outros aspectos se anunciam às temáticas em relevo, os quais 
provocam deslocamentos das cores, ora tidas como do pavão, que metaforizam as (des)venturas, reconhecidas pelas ambivalências que contrapõem códigos e características do gênero, a exemplo de um humor ocultado, que se revela pelo "sempre", apoteoticamente.

Seria a ausência do riso a negação do humor? Ou a presença do humor que não é transbordado pelo riso? Tais questões são aludidas ao poema narrativo de Rezende, no qual se metamorfoseiam o riso, a dor, o sofrimento e a angústia no fantástico, ora dramático, ora trágico, lidado aqui como riso rústico, ou ainda o riso greco-romano. Para Minois:

\begin{abstract}
[o] riso está presente por toda a parte do mundo romano. O riso sob todas as suas formas, positivas e negativas, sutis e grosseiras, agressivas e indulgentes, que a língua latina concentra em uma única palavra: risus. O riso, multiforme, permanece riso, do trocadilho grosseiro ao humor mais fino, passando pelo grotesco, pelo burlesco, pela ironia, pela zombaria, pelo sarcasmo. (MINOIS, 2003, p. 78).
\end{abstract}

Desse modo, o riso rústico se insere nessa perspectiva, mesclando-se pelo diálogo cultural de vivência e produção de conhecimento pelas civilizações greco-romanas. A raiz antiga do mito romano ecoa em outras culturas ocidentais, para além do grego, em interface a sujeitos que se constroem heróis, provocando o nascimento de novos gêneros, a exemplo da comédia, sem ser risível, porém cômico. Sobre essa vertente, olha-se para esse sujeito em paralelo às características mais notáveis em arenas, impérios, maculando o perfeito e o viril, sem descartar vozes de poetas e narradores que avivaram o riso na tradição popular.

Nesse sentido, o legado greco-romano modela o riso ${ }^{1}$, que alcança produções posteriores, a exemplo das produções nacionais, de modo que os rituais épicos são tangenciados pelas inserções de categorias e/ou elementos, emulando um novo gênero pela forma ou pelo conteúdo. Faz-se saber que, na tradição épica, as vozes se mostram pelas narrativas, a exemplo das aventuras e desventuras homéricas, no entanto, pode-se observar que esses feitos são ressignificados pelo lirismo canônico ou popular.

Tangente ao cânone, a poesia popular aproxima o homem sertanejo do que outrora apenas os ditirambos forjavam. Assume o comando o poeta popular, figura central da literatura de cordel, capaz de revelar uma nova Helena de Troia, com nome de Creuza, como a donzela que desperta em Evangelista o amor, assim como fez a mulher mais bela ao promover a guerra entre gregos e troianos.

\footnotetext{
${ }^{1}$ Ecoa-se, pois, o legado aristotélico quando aborda o riso junto ao nascimento da comédia, uma vez que trata a comicidade como defeito; no entanto, o efeito do riso não se volta à graça, nem pode ser tomada como inferior ao trágico, pois não se trata de juízo de valor. Como dito, a leitura do riso é modelada pelo sentido greco-romano, especialmente ao que tange à imitação humana, logo se tornando motivo para o engraçado, o risível, na contemporaneidade, aqui exemplificada pelo $O$ romance do pavão misterioso.
} 
Projetam-se, então, elementos composicionais do poema épico, em que a Proposição, a Invocação e a Narração, por mais que não obedeçam à configuração greco-romana, anunciam o mote, o herói e o enredo, os quais argumentam ao longo da narrativa, em verso ou prosa, situações que se assemelham à tragédia, na produção em análise.

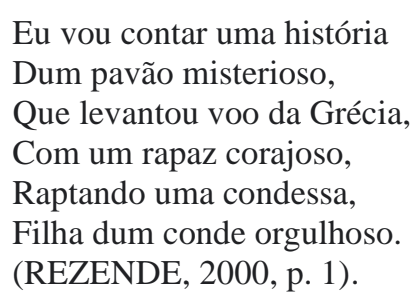

Em caráter de equivalência, pode-se afirmar que a estrofe projeta a proposição do poema, porém, como não se objetiva um trabalho comparativo, tão pouco de buscar equivalentes entre o épico grego e o contemporâneo brasileiro, enfatiza-se, pois, que pelas ressonâncias da tragédia grega, que ecoam ambivalências com o cômico, busca-se identificar em $O$ romance do pavão misterioso situações que recriam o riso, já que "o caráter bem-humorado percorre quase toda a literatura popular" (MARINHO; PINHEIRO, 2012, p. 98).

Formas incomuns a esse humor vão redimensionar o riso, de modo que revelam faces ocultas dos personagens ou do próprio enredo, as quais convergem, por mais paradoxais que se mostrem, a exemplo do humor e do fantástico. No romance, a expressão do fantástico pode ser associada ao conto de fadas, uma vez que apresenta aspectos comuns com esse gênero, como foram destacados àqueles voltados à épica. Em discussões atuais, essas aproximações poderiam eclodir nos esteios do gênero híbrido, o que não convém aprofundamentos, dada a opção de articular dualidades e/ou ambivalências que promovem a ressignificação do riso.

É comum que o humor na literatura popular se revele pelo riso, provocado em disputas de cantadores, em pelejas, resultando em episódios engraçados, em que o riso "corre frouxo", porém, contrapõe-se ao engraçado o riso que é ocultado, seja pela angústia, pela dor, pelo sofrimento, ou, ainda, pela tirania, como a ação do conde, pai de Creuza, ao mantê-la presa em seu castelo, com aparição anual no alto da torre, como se exibisse um troféu, desconsiderando vontades e desejos da condessa.

Dessa forma, prenuncia-se o rapto do riso em $O$ romance do pavão misterioso, como entrave que tangencia o "viveram juntos para sempre", postulado por Marinho e Pinheiro. Um conto de fadas às avessas? "O humor pode nascer de situações inusitadas, de versos cheios de nonsense, de deslocamentos os mais diversos" (MARINHO; PINHEIRO, 2012, p. 102). Neste caso, aposta-se no deslocamento, o qual justificaria os contrários do conto de fadas, porém, por 
se tratar da ausência do riso, o que não significa exclusão do humor, o inusitado se mostra pelo declive dos direitos, ora negados à condessa, que também oculta sua felicidade.

Mesclam-se, no romance citado, ressonâncias do épico e do conto de fadas, enfatizando os elementos insólitos, os quais se distanciam do verossímil. Aspectos que poderiam ser analisados como constituintes do cordel; no entanto, olha-se aos deslocamentos possíveis que permitem enxergar o riso metamorfoseado pela expressão da felicidade àquele que disfarça o sofrimento. A imagem da princesa se atualiza como a condessa Creuza, vítima da tirania do pai e mantida prisioneira, e não conta ser salva por um príncipe, porém, conhece seu amado Evangelista, que chega pelo teto trazido por um pavão, e não a cavalo, provocando o riso, até então raptado pelo próprio pai. Sendo o pavão a presença do insólito, corrobora aqui a ideia do maravilhoso, paralelamente construída à teoria defendida por Tzvetan Todorov (2017), quando afirma que "O fantástico é a hesitação experimentada por um ser que só conhece as leis naturais, face a um acontecimento aparentemente sobrenatural" (p. 31).

Dessa forma, Remo Ceserani complementa a noção de fantástico de Todorov, fazendo-a se ampliar, uma vez que:

[a] escolha de se fechar o máximo possível dentro da terminologia de Todorov e dos outros estudiosos que têm dedicado tempo e paciência à exploração dos textos de modo fantástico dos séculos XIX e XX é obrigada a combater algumas tendências muito fortes e generalizadas para ter qualquer possibilidade de sucesso. (CESERANI, 2006, p. 10).

A ideia defendida por Ceserani, de que não se pode olhar para os elementos do insólito apenas pelo viés todoroviano, coloca o maravilhoso em perspectiva ao fantástico amplamente difundido entre os séculos recentes. Para o leitor, o pavão é maquinário, invenção tecnológica do homem chamado Edmundo, embora no jogo ficcional os demais personagens vislumbrem mistério, coisa de outro mundo:

\footnotetext{
O grande artista Edmundo

Desenhou nova invenção,

Fazendo um aeroplano

De pequena dimensão,

Fabricado de alumínio

Com importante armação.

Movido a motor elétrico, Depósito de gasolina, Com locomoção macia

Que não fazia buzina

A obra mais importante

Que fez em sua oficina.
} 
Tinha cauda como leque,

As asas como um pavão

Pescoço, cabeça e bico,

Alavanca, chave e botão.

Voava igual a vento

Para qualquer direção.

Eu fiz um aeroplano

Da forma de um pavão,

Que de arma e se desarma,

Comprimindo um botão,

E carrega doze arrobas

Três léguas acima do chão.

(REZENDE, 2000, p. 11-12),

A invenção de Edmundo contraria as características originais da ave, que apresenta voo desengonçado e barulhento, tendo suas cores substituídas pela uniformidade do alumínio, uma "locomoção macia/ Que não fazia buzina". O foco não é mostrar a inventividade que voa, mas como se torna metáfora na narrativa que promove o rapto às avessas, uma vez que o sorriso da condessa ocultado pelo conde é devolvido ao ser raptada por Evangelista, que usa o aeroplano na fuga.

A nuance do fantástico em $O$ romance do pavão misterioso não é um exemplo do mais categórico, até porque vislumbra-se uma intersecção que torna o gênero híbrido, seja pela forma ou pelo conteúdo que mesclam elementos do real com o ficcional, do clássico com o contemporâneo etc.

O conto de fadas é revisitado por alguns índices que antecipam o riso da felicidade, linearmente. O horário da meia noite que remete ao momento que o feitiço é desfeito em Cinderela, aqui é momento que parte Evangelista ao encontro de Creuza:

\footnotetext{
À meia-noite o pavão

Do muro se levantou;

Com as lâmpadas apagadas,

Como uma flecha voou.

Bem no sobrado do conde,

$\mathrm{Na}$ cumeeira aterrou.

$[\ldots]$

Chegou ao quarto de Creuza,

Onde dormia a donzela,

Debaixo dum cortinado

Feito de seda amarela,

E ele, para acordá-la,

Pôs a mão na testa dela.

A moça estremeceu,

Acordou no mesmo instante

E viu um rapaz estranho
} 
De rosto muito elegante,

Que sorria para ela,

Com um olhar fascinante.

(REZENDE, 2000, p. 13-14).

O sono, que rememora o conto de fadas A Bela Adormecida, pelo imaginário do conto clássico, reverbera a "princesa" em $O$ romance do pavão misterioso é surpreendida pela chegada do "príncipe", inclusive pelo inusitado, estranho sujeito que adentra o quarto da jovem donzela. Não que Creuza esperasse ser acordada por Evangelista, no entanto, ao ser despertada de seu sono, penumbra-se o riso, até então negado de todas as formas, sendo possível vislumbrar sua liberdade através do "rosto muito elegante/ Que sorria para ela".

A chegada do pavão, à meia noite, pela fresta aberta no telhado, é vislumbre para Creuza de distanciamento do real, aproximando do “[...] fantástico, isto é: uma certa reação diante do sobrenatural; mas também, ao próprio sobrenatural” (TODOROV, 2017, p. 166). Subtrai-se daí uma parcela da angústia na vida de Creuza, de modo que não equaciona, pois o medo visita seus pensamentos, a estremece e provoca o grito, evocando o pai, mesmo abusivo, para enfrentar o desconhecido. Da liberdade roubada, disfarçada pela proteção paterna, à alegria provocada pelo pedido de casamento, também inusitado, quando:

$$
\begin{aligned}
& \text { O rapaz lhe disse: - Moça, } \\
& \text { Entre nós não há perigo: } \\
& \text { Estou pronto a defendê-la } \\
& \text { Como verdadeiro amigo. } \\
& \text { Venho é saber da senhora } \\
& \text { Se quer se casar comigo. } \\
& \text { (REZENDE, 2000, p. 14). }
\end{aligned}
$$

Distante do factual, mais um inusitado evento se passa no plano da ficção: trata-se do tom de ameaça logo descontruído pelo rapaz desconhecido, alegando ele que não há perigo. Como é possível? O tempo ficcional abrevia o entendimento entre o casal, e logo se estabelece a confiança, apesar de haver relutância da moça desde a convocação do pai e paciência do já apaixonado Evangelista. O pedido de casamento demarca o compromisso, o bom caráter do moço e suas boas intenções, promovendo mais um paradoxo - de um lado a possibilidade do riso, do outro, sua ocultação, pois, diante do recuo e confiança ainda não firmada, Creuza tenta convocar seu pai para defendê-la, antes de ser inebriada pelo lenço, parte da invenção de Edmundo que serviria no rapto da condessa grega.

$\mathrm{O}$ medo omite o riso, consequência de ter o quarto invadido pelo pretendente e pelo disparate colérico do pai, ambos impulsionando Creuza ao conflito: 


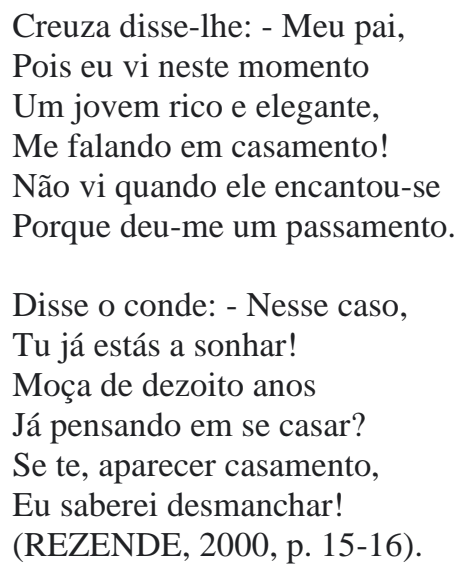

Tanto o pai quanto o amado são implicados no dilema que assola a vida de Creuza. Dividida entre o sonho e o real, o medo e a alegria, imagina a moça estar sonhando, ao mesmo tempo em que é despertada do sonho pela valentia do pai e, instável na crença de que fora pedida em casamento, revela sobre a visita do pretenso noivo. A juventude marcada pelos dezoito anos aguça o território da dúvida de Creuza, refutada pelo argumento do pai, que também revela a relação de poder, demarcado pelo tom autoritário que exclui o riso da vida da filha.

Ao lado da censura institucionalizada, existe uma outra, mais sutil e mais geral: a que reina na própria psique dos autores. A condenação de certos atos pela sociedade provoca uma condenação que se exerce dentro do próprio indivíduo, constituindo-se para ele em proibição de abordar certos temas tabus. (TODOROV, 2017, p. 167).

Neste caso, o casamento é visto como saída da clausura, da soberania masculina e paterna, que longe dela se almeja paz e felicidade, ou seja, novas formas de riso. Mistura-se, nesse riso, características do ingênuo, do apoteótico, do rústico e do fino, resultando em um humor plural, multiforme, excluindo-se a ironia e o sarcasmo, entre outros que carregam nuances do humor sombrio.

O encantamento vai além do índice de fantástico e/ou deslocamento da dor/sofrimento, tornando figurativa a possibilidade da mudança da realidade ora vivida. O sonho é trilha possível para o riso aprisionado, busca libertar-se do poder, da tirarnia e da solidão, estes talvez impostos pela condição de condessa, sufocada pelo medo, proporcionalmente distribuído na (des)confiança do jovem encantado que lhe pede em casamento e na angústia pela restrição de território físico e sentimental determinada pelo pai. 
Que enfeita puramente,

Como um anjo terreal

Que tem lábio sorridente.

(REZENDE, 2000, p. 16).

Mais uma vez a ambivalência é cerne do interior da narrativa, que dilata a visão do leitor enquanto apura as delimitações territoriais da princesa "Como um anjo terreal/ Que tem lábio sorridente". É possível atenuar pelo sono a ausência do riso que transita pelo irreal, ou seja, Creuza em seu leito dorme "o sono inocente", no qual se refugia do sofrimento provocado pelo tolhimento do patriarcado.

O conde e Evangelista desempenham papéis antagônicos, porém, cabendo ao leitor perseguir os caminhos do herói e do vilão, uma vez que "O leitor e o herói, como vimos, devem decidir se tal acontecimento, tal fenômeno pertence à realidade ou ao imaginário, se é ou não real" (TODOROV, 2017, p. 175).

\footnotetext{
Creuza achou impossível O moço entrar no sobrado, Então perguntou a ele De que jeito tinha entrado E disse: - Vá me dizendo Se é vivo ou encantado!

- Como eu lhe tenho amor, Me arrisco fora de hora. Moça, não negue o sim A quem tanto lhe adora! Creuza ai gritou: - Meu pai! Venha ver o homem agora! (REZENDE, 2000, p. 17).
}

Rompem-se o sono, o sonho e o telhado que amparam Creuza quando Evangelista adentra o recinto, obliterando o encanto em função do retorno à realidade. Creuza impõe-se ao exigir do visitante uma explicação, já que suas intenções de casar lhes foram postas em encontros anteriores, para além da desconfiança; ela empenha-se em desnudar os pequenos entraves que tornem (im)possível a união que se dará pela fuga daquele sobrado. Dois mundos se cruzam neste momento de tensão, que também dividem a jovem donzela, propiciando a intercorrência do pai, o qual não hesita em surpreender diante do chamamento da filha, de modo que as visitas de Evangelista feriam seu ego e sua autoridade de conde.

As múltiplas facetas do fantástico acabam por auxiliar na compreensão ambivalente dos eventos intrínsecos à obra, talvez a imprecisão que se instaura entre a literatura geral e a fantástica. O tom fantástico é impresso em $O$ romance do pavão misterioso, e sem pretensão de afirmá-lo como narrativa fantástica, ecoa o sobrenatural, pois é: 
[...] aquilo que transgride as leis que organizam o mundo real, aquilo que não é explicável, que não existe, de acordo com essas mesmas leis. Assim, para que a história narrada seja considerada fantástica, deve-se criar um espaço similar ao que o leitor habita, um espaço que se verá assaltado pelo fenômeno que transformará sua estabilidade. (ROAS, 2014, p. 31).

Nessa perspectiva observa-se que:

\author{
Só sendo uma visão, \\ Que entra neste sobrado! \\ Só chega a meia-noite, \\ Entra e sai sem ser notado \\ E se é gente deste mundo, \\ Usa feitiço encantado! \\ (REZENDE, 2000, p. 18).
}

Menciona-se "visão" como elemento sobrenatural, não pertencente ao mundo dos vivos, pondo em relevo os mundos possíveis pela ficção, apesar de contrapor verdades, as quais se mesclam pelo improvável, não assustam nem repelem, mesmo que o "feitiço encantado" seja passível de (des)encontros do riso e da felicidade. Creuza concede ao pai permissão, que vai interferir nos planos de sua felicidade em detrimento da dúvida de que Evangelista seja real ou de outro mundo. Outra anotação importante se volta ao horário, reverberando o tom do conto da Cinderela, que à meia-noite se desmancha o encanto que aqui se inicia.

David Roas (2014) defende a premissa de que nem "toda a literatura com intervenção do sobrenatural deva ser considerada fantástica.” (p. 30), no entanto, o sobrenatural é o cerne do gênero, bem como suas ressonâncias não negam a influência em outros gêneros, tampouco em outras narrativas. Ou seja, O romance do pavão misterioso não é categorizado como narrativa fantástica, porém oferece ao leitor elementos fantásticos, os quais provocam deslocamentos do real pelo sobrenatural, por mais efêmero que se construa.

Essa hibridez que se nota pela forma, pelo conteúdo e pelas vozes narradas, amplia a perspectiva do leitor quando:

\footnotetext{
Evangelista sentou-se

Pôs-se a conversar com ela.

Trocando riso, esperava

A resposta da donzela.

Ela pôs-lhe a mão na cabeça,

Espalhou a banha amarela.

(REZENDE, 2000, p. 19).
} 
Sem ter a certeza de que o cortejo principiava a verdade, Creuza põe em prática o plano do pai, marcando Evangelista com banha amarela, a fim de que os soldados do conde rastreassem o "encantado" ou homem de carne e osso. O riso trocado, que em outros contextos conotaria a cumplicidade, especialmente dos amantes, é relutado por Creuza e põe em dúvida o sentimento declarado pelo pedido de casamento, mas ainda não é "a resposta da donzela".

Dessa maneira, há o questionamento em forma de dúvida por parte de Creuza que, apesar de manter características ressonantes da princesa, reveste-se de nuances do real, aceitando participar do plano do pai, que é desmascarar o encantado visitante de seu sobrado. Para Propp (2002, p. 25), sobre as produções posteriores às produções primitivas, "[e]m tais casos, podese recorrer à épica heroica na falta de outro material".

Creuza protagoniza uma narrativa que exemplifica essa produção posterior, unindo elementos do maravilhoso e do épico, excetuando-se ao herói características que deslocam as aventuras e desventuras clássicas, como é possível no conflito a seguir:

Creuza, sabendo da história,

Chorava, arrependida

Por ter marcado o rapaz

Com a banha desconhecida.

Disse: - Nunca mais terei

Sossego em minha vida!

Disse Creuza: - Ora papai

Me priva da liberdade

Não consente que eu goze

A distração da cidade!

Vivo como criminosa,

Sem gozar a mocidade!

Aqui não tenho direito

De falar com um criado.

Um rapaz, para me ver,

Precisa vir encantado.

Mas talvez que ainda eu fuja

Deste maldito sobrado!

O rapaz que me tem amor,

Só queria vê-lo agora,

Para cair em seus pés

Como a infeliz que chora

Embora eu, ao depois,

Morresse na mesma hora!

Eu sei bem que, para ele,

Não mereço mais confiança

Enquanto ele vinha aqui,

Ainda eu tinha esperança

De sair desta cadeira

Que dá sentença à criança! 


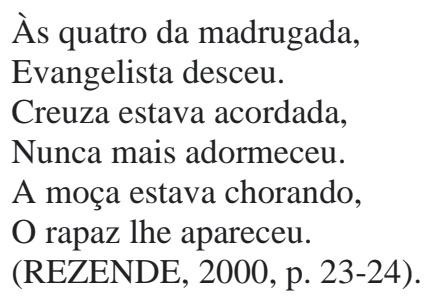

A ausência do sono implica no distanciamento do riso, já que o adormecer para Creuza permite a alegria, o encontro com a felicidade mesmo que na clandestinidade, momentaneamente, estabeleçam conexões amorosas despertadas pelas visitas do turco. Creuza e Evangelista reescrevem o trágico acontecimento protagonizado por Helena de Troia, em que o confronto é dramático, e a guerra menos sangrenta, porém com conflitos parecidos.

Estudos anteriores tentam explicitar ambiguidade, como a amostragem feita por Desmeules acerca do humor no território do fantástico, ao exemplificar com Freud e suas observações no tocante às ambivalências desses gêneros. Dessa forma, acentua-se a ligação possível entre os aspectos paradoxais, como se observa o "aterrorizante e o divertido", "o humor e o fantástico", "o maravilhoso e o verossímil”, entre outros.

Demora-se, mas acontece a reviravolta quando a resolução do conflito vem à tona pelo desnudamento das personagens masculinas que intervêm na vida de Creuza, ambos sob a tutela de proteção, pai e futuro esposo: o primeiro reprime o riso, enquanto que o segundo anuncia o riso desde a sua chegada em território grego, arquiteta planos e trava batalhas até a sua chegada no sobrado, arranca o mais ingênuo sorriso até ser suspenso pela desconfiança da donzela, que se permite ser livre da masmorra paterna.

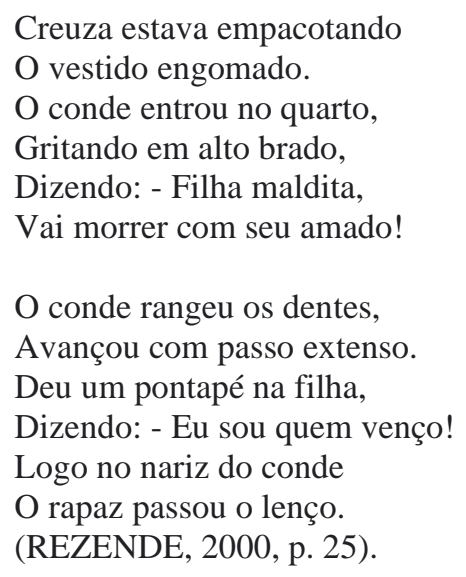

O empacotamento do vestido alude à despedida da atual situação e ao aceite do pedido de casamento do estrangeiro Evangelista, bem como ao despertar da ira do pai, anunciada pela sentença de morte da filha e do futuro esposo, "Dizendo: - Filha maldita, / Vai morrer com seu 
amado!". O ranger dos dentes adiciona à ira do conde o tom irracional, pois "Deu um pontapé na filha", intentando vitória sobre o decente rapaz, que tinha as melhores intenções com a herdeira do trono. Nessa perspectiva, um diálogo é estabelecido em linha tênue, envolvendo ambivalências que se estreitam no redimensionamento de personagens, ora ligadas ao fantástico, ora ao mundo factual, consonantes com "A linha entre angústia e riso surge linhas pontilhadas tão finas que a osmose é possível, o que leva à ambivalência do riso amarelo - ou negro (FABRE apud DESMEULES, 1997, p. 12, tradução nossa). ${ }^{2}$

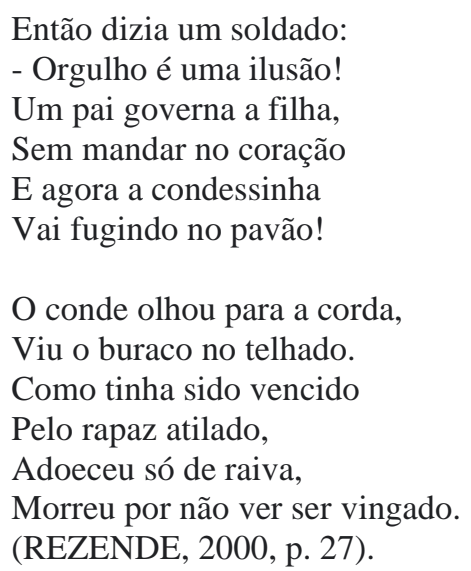

A derrota do conde é plasmada pelo olhar de um soldado que aponta o orgulho e a tirania do pai, defeitos comuns aos sujeitos soberbos e valentes que ignoram a força dos bons sentimentos. O conde malogra o coração da própria filha quando põe em relevo seu egoísmo e desvirtua sentidos ao "governá-la", esquecendo-se de ser ela independente no que se vincula o coração, tratando a filha como prenda que surge uma vez por ano na torre do sobrado, para alimentar o imaginário do povoado grego. O referido ritual perpassa o território grego pela fotografia levada por João Batista ao irmão Evangelista que, após dias de glória e vencer o conde, foge com a condessinha em seu aeroplano com formato de pavão. Enquanto o pavão auxilia na devolução do riso de Creuza, levando-a daquela prisão, seu pai não aceita a derrota, morre após ser acometido pela raiva e não reconhece a vitória "Pelo rapaz atilado".

\footnotetext{
Logo que Evangelista

Foi chegando na Turquia

Com a condessa da Grécia,

Fidalga da monarquia,

Em casa de João Batista

Casou-se no mesmo dia.
}

\footnotetext{
${ }^{2}$ No original: "La frontière entre l'angoisse et le rire se dessine en pointillés si ténus qu'une osmose est possible, qui mène à l'ambivalence du rire jaune — ou "noir"”.
} 


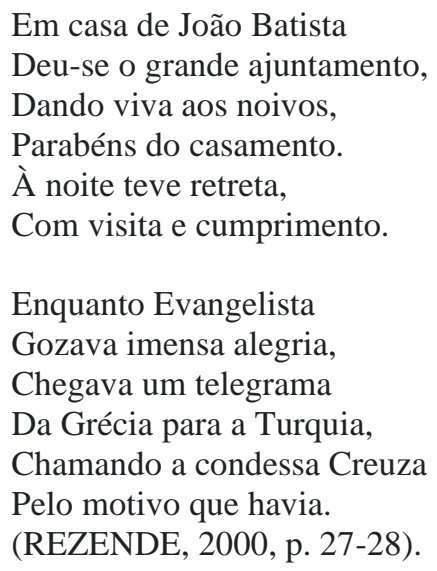

A busca pela felicidade assume nuance da pressa, intercalada pela penumbra da eternidade, em que instantes parecem devolver o sorriso da condessa, ao enterrar junto ao pai as agruras que lhe raptavam o riso. Ao chegar à Turquia, em casa de João Batista, o opositor do riso é silenciado pela alegria, consolidada pelo casamento do casal que alçou voo da Grécia à procura de paz, "casou-se no mesmo dia". O tempo narrado abrevia os eventos que distanciavam o júbilo de Creuza e Evangelista; após cumprirem os protocolos da festiva comemoração, os noivos gozam de "imensa alegria", exemplo que:

Também aborda a questão da participação do personagem para o fantástico, invocando o prazer ambivalente despertado no leitor por esta aparente complacência do protagonista em uma situação que, no entanto, desestabiliza o universo fictício que ele vive. (DESMEULES, 1997, p. 13, tradução nossa). ${ }^{3}$

Esse entendimento é possível pelas verdades postas nos mundos fictício e real, verdades possíveis em cada plano, bem como pelo elo estabelecido com o sobrenatural e o maravilhoso, ambos rememorados. Entretanto, o caráter verossímil se sobrepõe, uma vez que, apesar do riso ser devolvido ao rosto de Creuza e ser materializado o "viveram juntos para sempre", as facetas do "improvável" são reveladas, a exemplo do "misterioso" pavão, inicialmente visto como elemento encantado da narrativa por alguns personagens e pelo leitor.

\footnotetext{
E também a mãe de Creuza

Já esperava vexada.

A filha mais tarde entrou,

Muito bem acompanhada,

De braços com seu noivo

Disse: - Mãe, estou casada!

Disse a velha: - Minha filha,
}

\footnotetext{
${ }^{3}$ No original : "Il aborde aussi la question de la participation du personnage au fantastique en invoquant le plaisir ambivalent suscité chez le lecteur par cette complaisance apparente du protagoniste dans une situation qui déstabilise pourtant l'univers fictif qu'il habite".
} 
Saíste do cativeiro!

Fizeste bem em fugir,

E casar no estrangeiro!

Tomem conta da herança

Meu genro é meu herdeiro!

(REZENDE, 2000, p. 30).

O rapto do riso não é mais uma ameaça para Creuza, que desfruta do casamento, metáfora do amor e da felicidade no plano da ficção, análoga a outras culturas ainda na contemporaneidade. É convocada pela mãe para retornar à antiga casa, na qual foi prisioneira e tinha aprisionado seu riso, para receber sua herança, fator que potencializa o "viveram juntos para sempre", uma vez que a viúva declara "Meu genro é meu herdeiro!”. A transferência do poder é mantida entre os homens, excetuando-se o bom caráter do marido - a mulher vive sob o julgo e o cuidado do patriarcado. Considere-se, pois, a diacronia estabelecida entre os séculos, justificando o tempo e abordagem que ressoam a figura masculina como determinante da condução dos papéis femininos.

Dessa forma, a assertiva de Thompson retomada por Desmeules (1997) "reconhece a ambivalência das vítimas nos textos do fantástico que hesitam entre a fuga e o confronto" reforça o comportamento das personagens de $O$ romance do pavão misterioso, especialmente no que concerne à chegada "encantada" de Evangelista no quarto de Creuza, à meia noite, guiado por um pavão misterioso, fato desconhecido dela.

\section{O pouso silencioso}

Algumas improváveis contradições na narrativa popular permitiram que surgisse o fantástico em $O$ romance do pavão misterioso; quando foi proposto "O rapto do riso", paradoxalmente estabeleceram-se aproximações com aquilo de aparência distante. Observouse o tom fantástico pelas cores do pavão, aqui metáfora de ambivalência que figurativiza o animal, mantendo o voo, só que silencioso e com suas cores substituídas pelo alumínio monocromático.

O humor na narrativa se assemelha ao épico heroico, em que o confronto suspende a expressão do riso. Optou-se, então, por um viés explicativo de que o riso ou as situações engraçadas foram tensionados pela angústia, pela dor e pelo sofrimento, em ambivalência ao ato ou ao efeito da alegria, ou ainda a felicidade.

Distanciada do riso, Creuza é personagem multifacetada em $O$ romance do pavão misterioso, é vítima do próprio pai, mantida em prisão domiciliar, enreda-se pelas características do verossímil e do maravilhoso, algo paradoxalmente possível em uma narrativa 
pós-épica que inscreve a beleza troiana, ressoa o conto de fadas e ressignifica o riso em seus desdobramentos, partindo, é claro, do rústico.

O humor é posto em relevo pelos fragmentos do factual e do maravilhoso, pela ambivalência da felicidade, que provoca a distância do riso, natureza paradoxal que surge como mecanismo que amortece o efeito do sofrimento e projeta a alegria, amalgamado pelo final glorioso, que rememora o riso apoteótico. Dessa forma, a fuga é opção ao confronto, que viabiliza aos personagens distinguirem as ambivalências que provocam o rapto do riso. Pelas dualidades identificadas na narrativa, imagens do maravilho, do clássico e do verossímil foram metamorfoseadas pela saga enfrentada por Creuza e Evangelista, que, por fim, "sorriem” juntos para sempre.

\section{Referências}

ARISTÓTELES. A poética clássica. Tradução: Jaime Bruna. 12.ed São Paulo: Cultrix, 2005.

CESERANI, Remo. O fantástico. Tradução: Nilton Cezar Tridapalli. Londrina: Eduel, 2006.

DESMEULES, Georges. La littérature fantastique et le spectre de l'humour. France: Instant même, 1997.

MARINHO, Ana Cristina; PINHEIRO, Hélder. O cordel no cotidiano escolar. São Paulo: Cortez, 2012.

MINOIS, Georges. História do riso e do escárnio. Trad. Maria Elena O. Ortiz Assumpção. São Paulo: Ed. UNESP, 2003.

PROPP, Vladímir. As raízes históricas do conto maravilhoso. Trad. Rosemary Costhek Abílio, Paulo Bezerra. 2 ed. São Paulo: Martins Fontes, 2002.

REZENDE, José Camelo de Melo. O romance do pavão misterioso. Fortaleza: Tupynanquim, 2000.

ROAS, David. A ameaça do fantástico: aproximações teóricas. Trad. Julián Fuks. São Paulo: Ed. UNESP, 2014.

TODOROV, Tzvetan. Introdução à literatura fantástica. Trad. Maria Clara Correia Castello. 4 ed. São Paulo: Perspectiva, 2017. 